\title{
Nile River Freshwater Quality Assessment at Assiut Governorate
}

\author{
M. A. Abdelal ${ }^{\mathrm{a}}$, M. Abdelfattah ${ }^{\mathrm{b}}$, A. Mostafa ${ }^{\mathrm{c}}$, d, Abd El-Latif \\ Heshame, *
}

${ }^{a}$ Assiut and New Valley Company for Water and Wastewater, Assiut, Egypt.

${ }^{b}$ Civil Engineering Department, Military Technological College, Muscat, Oman.

${ }^{c}$ Geology Department, Faculty of Science, Assiut University, Egypt.

${ }^{d}$ National Water and Energy Center, United Arab Emirates University, Al Ain, UAE.

${ }^{e}$ Genetics Department, Faculty of Agriculture, Beni-Suef University, Beni-Suef, Egypt.

* Corresponding author: Prof. Abd El-Latif Hesham, Genetics

Department, Faculty of Agriculture, Beni-Suef University, Beni-Suef 62511, Egypt. Tel: +2-01012115256,

Email:hesham_egypt5@agr.bsu.edu.eg; hesham_egypt5@aun.edu.eg

\section{Abstract}

The Nile River is the longest in Africa and is one of the most important sources of freshwater. Water specifications vary along the course of the river, which represents the main source of drinking water in Egypt, with depends on the treatment of raw freshwater by conventional plants to get rid of the main pollutants of freshwater, such as suspended particles (turbidity) and microorganisms, therefore assessment of the characteristics of freshwater of the river over long period and studying it opens many horizons for establishing of new techniques for treating the freshwater.

The main objective of this study is to monitor the Nile River over a period at the study area Assiut-Egypt, as this study shows that the Nile River contains large quantities of bacteria with an average $1645 \mathrm{CFU} / \mathrm{ml}$ throughout the year in different seasons those affects the numbers of these bacteria, in addition to the river contains moderated concentrations 
of total dissolved solids with an average $216 \mathrm{ppm}$, and the average turbidity is about $4.7 \mathrm{NTU}$, while the average value of $\mathrm{pH}$ was 8.2 , as well as confirming the low concentrations of iron as the average was $0.04 \mathrm{ppm}$, moderate concentrations of chloride as its average was 15 $\mathrm{ppm}$, and low concentrations of ammonia as the average was $0.06 \mathrm{ppm}$. Therefore, this study is an assessment of the Nile River water specifications to prove that the freshwater required to be treated of the non-complied values of bacteria and turbidity concerning the Egyptian drinking water standards.

Keywords: Freshwater quality, Nile river water, Drinking water treatment, Freshwater bacterial count.

\section{Introduction}

The Nile is Africa longest river, and it considered as the world longest river as the Nile is about 6,650 kilometers long [1], with eleven countries in its drainage basin: Tanzania, Uganda, Rwanda, Burundi, the Democratic Republic of the Congo, Kenya, Ethiopia, Eritrea, South Sudan, Republic of the Sudan and Egypt. In particular, the Nile River is the main water source in Egypt.

The White Nile and the Blue Nile are two main tributaries of the Nile. The White Nile is known to be the Nile headwaters and main stream. The Blue Nile, which starts at Lake Tana in Ethiopia and flows into Sudan from the southeast, is the source of the majority of the water, comprising $80 \%$ of the water and silt. The two rivers come together just north of Khart, Sudan capital.

The river flows almost entirely north through the Sudanese desert to Egypt, where Cairo is situated on a huge delta and the river empties into the Mediterranean Sea at Alexandria. Since ancient times, the river has been vital to Egyptian culture and Sudanese kingdoms.

Fresh water stocks account for (35 million km3), or just 2.5 percent of the entire water supply in the hydrosphere. In the Antarctic and Arctic areas, a major portion of the fresh water (24 million $\mathrm{km} 3$, or $68.7 \%$ ) is in the form of ice and permanent snow cover. Fresh water lakes and rivers, which provide the majority of human water, hold an average of $90,000 \mathrm{~km} 3$ of water, or 0.26 
percent of total global fresh water reserves [2]. Only through the water cycle phase in which water from oceans, streams, forests, soil, rivers and reservoirs evaporates, forms clouds, and returns as precipitation can freshwater be replenished. Locally, however, if more freshwater is consumed than is naturally restored by human activities, this can lead to a decreased supply of freshwater from surface and underground sources and can cause significant harm to the surrounding and related ecosystems.

The rise in the world population and the rise in per capita water usage are putting growing pressures on the supply of safe freshwater for limited resources. The World Bank adds that the response by freshwater ecosystems to a changing climate can be defined in terms of three interrelated components: water quality, water quantity or volume and water timing. A transition in one also frequently leads to changes in the other [3]. The availability of freshwater often decreases affected by pollution and subsequent eutrophication.

The most common and widespread health risk associated with drinking water is infectious diseases caused by pathogenic bacteria, viruses, and parasites (e.g., protozoa and helminths). The public health burden is determined by the magnitude of the pathogensrelated disease(s), their infectivity and the exposed population. There is a diversity of diseases that can be spread by polluted drinking water [4].

Many studies considered the quality of the Nile River water; that led to there is a continuous degradation of the water quality, because it is not capable to achieve a natural cleansing action [5]. Another study was to see the feasibility of using the Nile water as a source for various activities like suitability for aquatic life and drinking [6]. Also another study where to evaluate the multipurpose uses of water and human activities are intense and also aims to reveal the interrelationships between different physical and chemical parameter studied [7].

This study aims to monitor and assessing the quality of the freshwater in the course of the Nile River over two years in the 
study area site at Assiut-Egypt of coordinates (latitude $27.175892^{\circ}$ longitude $31.203474^{\circ}$ ), by collecting Nile River freshwater samples and performing laboratory bacteriological analysis as Heterotrophic Plate Count (HPC) to assess the vitality of bacteria, and other physical and chemical analysis such as turbidity, conductivity, temperature, iron, manganese, ammonia, chlorides, calcium and magnesium ions, then performing statistical analysis of these results to form overall view of the Nile River freshwater quality.

\section{Materials and Methods}

\section{Samples collecting}

The collection of samples from the course of the Nile River in the study area is relied on the manual method using a plastic container tied to a rope that is lowered to the course of the river in an area of good flow of the current and the analyzes are carried out immediately without the need to preserve the sample.

\section{Analytical techniques}

The overall laboratory analytical methods is based on the Standard Methods for the Examination of Water and Wastewater which is a joint publication of the American Public Health Association (APHA), the American Water Works Association (AWWA), and the Water Environment Federation (WEF), as it the biggest reference of the water and wastewater analysis.

Bacteriological analysis performed by using the Heterotrophic plate count spread process, bacteria were counted in raw and treated water inlets, as well as plate samples. 0.1 and 0.5 $\mathrm{ml}$ of sample are rotated on solidified plate count agar petri dishes, which are then incubated at $35^{\circ} \mathrm{C}$ for $48 \pm 3$ hours. The colonies on the dishes were counted with the dilution factor of withdrawn distributed volumes of samples on petri dishes in mind. In order to provide accurate results, duplicate and blank samples were obtained as quality control measures in this analysi [8].

The physical analysis performed on the raw freshwater to assessment the quality were total dissolved solids (TDS) and 
turbidity. Total dissolved solids were calculated using the electrical conductivity (EC) process, which is a measure of a solution's ionic activity in terms of its ability to transmit current. Turbidity of the sample was determined using the nephelometric process, which compares the intensity of light scattered by the sample under given conditions to the intensity of light scattered by a standard reference suspension under the same conditions using a turbidimeter instrument [8].

The Chemical analysis performed on the raw freshwater to assessment the quality were $\mathrm{pH}$, chlorides, ammonia and total iron. The $\mathrm{pH}$ were measured using an electrochemical cell for $\mathrm{pH}$ measurement always consists of an indicating electrode, whose potential is directly proportional to $\mathrm{pH}$, a reference electrode, whose potential is independent of $\mathrm{pH}$, and the aqueous sample to be measured. If all three parts are in contact with each other, a potential can be measured between the indicating electrode and the reference electrode, which depends on the $\mathrm{pH}$ of the sample and its temperature [8].

The amount of iron in the sample was measured using the phenanthroline colorimetric process, which involves boiling the solution with acid and hydroxylamine, then treating it with 1, 10phenanthroline at $\mathrm{pH} 3.2$ to 3.3 , and measuring the colorimetric absorbance with a UV-spectroscopy instrument at $510 \mathrm{~nm}$ wavelength. Chloride was measured by titrimetric method, which is based on silver nitrate titration of the sample until the endpoint on a pinkish yellow color appearing. Ammonia was analysed using the phenate method as an intensely blue compound, indophenol, which is produced by the reaction of ammonia, hypochlorite, and phenol catalysed by sodium nitroprusside and colorimetrically measured using a UV-spectroscopy instrument at $640 \mathrm{~nm}$ wavelength [8]. 
Table (1) the laboratory experimental performed analysis.

\begin{tabular}{|c|c|c|}
\hline $\begin{array}{c}\text { Analysis } \\
\text { category }\end{array}$ & Analysis & $\begin{array}{c}\text { Method no. } \\
\text { in APHA }\end{array}$ \\
\hline Bacteriological & Heterotrophic plate count (HPC) & $9215 \mathrm{C}$ \\
\hline \multirow{2}{*}{ Physical } & Total dissolved solids (TDS) & $2540 \mathrm{C}$ \\
\cline { 2 - 3 } & Turbidity & $2130 \mathrm{~B}$ \\
\hline \multirow{3}{*}{ Chemical } & pH value & $4500-\mathrm{H}^{+}$ \\
\cline { 2 - 3 } & Iron & $3500-\mathrm{Fe} \mathrm{B}^{-}$ \\
\cline { 2 - 3 } & Chloride & $4500-\mathrm{Cl}^{-} \mathrm{B}$ \\
\cline { 2 - 3 } & Ammonia & $4500-\mathrm{NH}_{3} \mathrm{~F}$ \\
\hline
\end{tabular}

\section{Results and Discussion}

\section{Bacterial viability observation:}

Since the examination of bacterial viability by HPC method were experimentally performed about (10) trials among the two years in different seasons to observe the change of the bacterial count over a large time scale, the results were obtained as in Table (2) and expressed in Fig. (1).

Table (2) Heterotrophic plate count of bacteria experiments results.

\begin{tabular}{|c|c|}
\hline \multirow{2}{*}{ Date } & HPC \\
\cline { 2 - 2 } & $($ CFU/ml $)$ \\
\hline $29 / 10 / 2018$ & 1300 \\
\hline $23 / 11 / 2018$ & 800 \\
\hline $28 / 01 / 2019$ & 800 \\
\hline $29 / 03 / 2019$ & 1400 \\
\hline $18 / 05 / 2019$ & 300 \\
\hline $19 / 11 / 2019$ & 500 \\
\hline $07 / 12 / 2019$ & 3000 \\
\hline $21 / 01 / 2020$ & 1800 \\
\hline $22 / 02 / 2020$ & 3600 \\
\hline $27 / 02 / 2020$ & 2950 \\
\hline
\end{tabular}


Fig. (1) Shows the variation of the bacterial count by HPC among the experiments performed period. It is clearly noticed, the change of bacterial count among the experiments period with dependent to the seasons change.

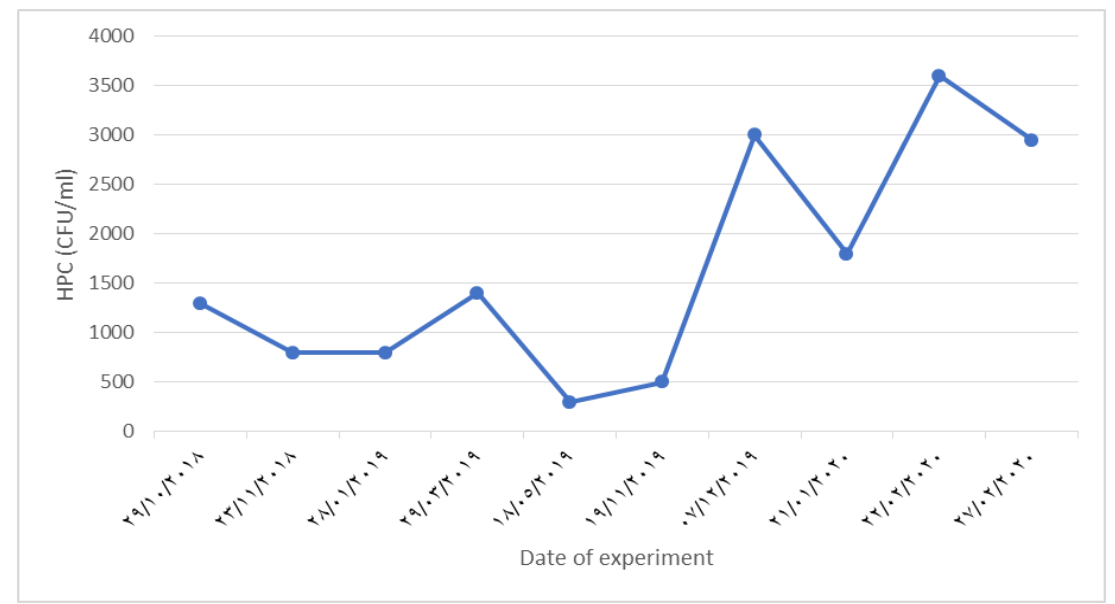

Fig. (1) Heterotrophic plate count versus the period of experiments.

All bacteria that use organic nutrients for growth are classified as heterotrophic bacteria. These bacteria can be found in all kinds of water, food, soil, plants and even the air. Primary and secondary bacterial pathogens, as well as coliforms, are included in this broad definition (Escherichia, Klebsiella, Enterobacter, Citrobacter and Serratia) [9]. The observed HPC results shows that the maximum bacterial count were $3600(\mathrm{CFU} / \mathrm{ml})$ at the winter season, and shows that the minimum bacterial count were 300 $(\mathrm{CFU} / \mathrm{ml})$ at the end of spring season, while the average value of the bacterial count was calculated as 1645 (CFU/ml), all obtained results for Nile River freshwater HPC show massive increment with reference to the established HPC limit in the Egyptian national drinking water standards of the Egyptian health minister decree 458/2007, which must not exceed $50 \mathrm{CFU} / \mathrm{ml}$.

The physical experiments were performed about (26) trials monthly among around two years to observe the change of the physical parameters over a large time scale, the results were expressed in Fig. (2 - a, b). 
Fig. (2 - a, b) Show the variation of the physical parameters (total dissolved solids (TDS) and turbidity) among the experiments performed period.

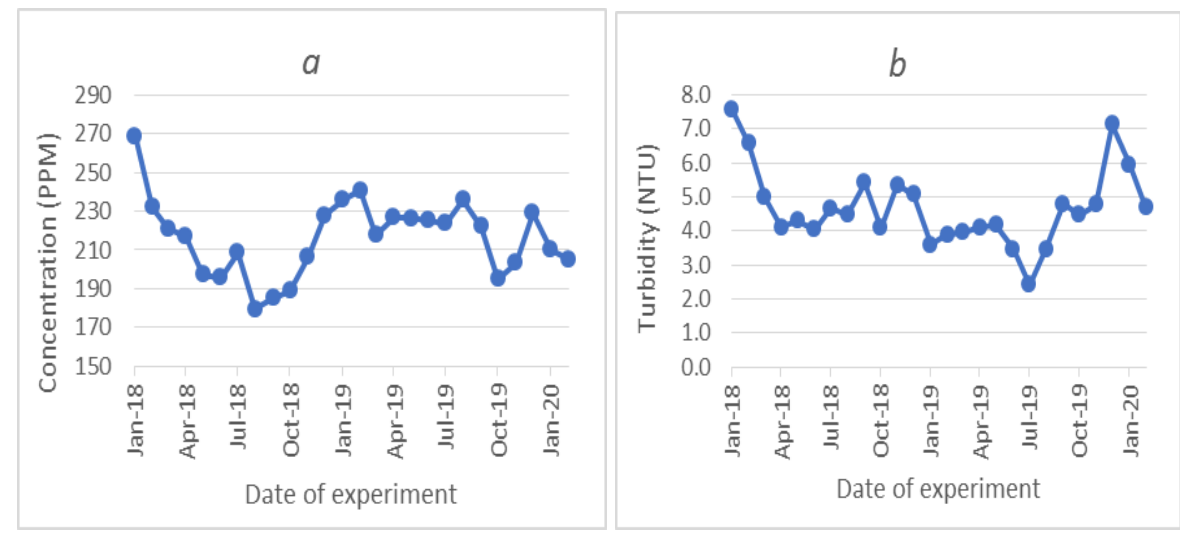

Fig. (2 - a, b) Physical parameters versus the period of experiments.

Total dissolved solids (TDS) expresses the amount of inorganic and organic substances dissolved in water. Inorganic ions involved in natural water involve carbonate, calcium, sulphate, chloride, sodium and other, mostly minor, constituents such as iron, copper, bromide or manganese [10]. Figs. (2 - a) shows the variation of the total dissolved solids in freshwater samples over the experiments period and it was observed that the maximum TDS concentration was $269 \mathrm{ppm}$, the minimum was $179 \mathrm{ppm}$, seasonally TDS average results were (231 ppm in winter, $218 \mathrm{ppm}$ in spring, $212 \mathrm{ppm}$ in summer and $200 \mathrm{ppm}$ in autumn) and the average value of TDS was calculated as $216 \mathrm{ppm}$.

All of the TDS resulted values comply the established limits of the TDS in the Egyptian national drinking water standards of the Egyptian health minister decree 458/2007, which must not exceed 1000 ppm.

While the study of Indices of water quality and metal pollution of Nile River, Egypt obtained seasonally TDS average results as $(259 \mathrm{ppm}$ in winter, $186 \mathrm{ppm}$ in spring, $179 \mathrm{ppm}$ in summer and $228 \mathrm{ppm}$ in autumn) with average of $213 \mathrm{ppm}$ over- 
year of 24 water quality monitoring sites were set up on the main stem of the river, covering $925 \mathrm{~km}$ along the Nile River [6].

Turbidity is a measure of complete suspended matter in aqueous solutions, which gives sign of clay, inert particles, and microorganisms [11]. Figs. $(2-b)$ shows the variation of the turbidity in freshwater samples over the experiments period and it was observed that the maximum turbidity value was 7.6 NTU, the minimum was 2.4 NTU, seasonally turbidity average results were (5.6 NTU in winter, 4.3 NTU in spring, 3.8 NTU in summer, and 4.8 NTU in autumn) and the average value of TDS was calculated as 4.7 NTU.

The obtained turbidity results of the Nile River water freshwater don't comply the established limits of the turbidity in the Egyptian national drinking water standards of the Egyptian health minister decree 458/2007, which must not exceed 1 NTU.

While the study of microbiological and chemical study of another site at El-Gezira, Cairo, Egypt - that northern of our study site by $375 \mathrm{~km}$ on the Nile River - obtained seasonally turbidity average results as (11 NTU in winter, 6.8 NTU in spring, 4.0 NTU in summer, and 6.5 NTU in autumn) with average of 7.0 NTU over-year [5].

With Turning to the chemical experiments were performed about (26) trials monthly among around two years - similarly to the physical experiments - to observe the change of the chemical parameters over a large time scale, the results were expressed in Fig. (3 - c, d, e, f). 
Fig. (3 - c, d, e, f) Show the variation of the chemical parameters (pH, iron, chloride, and ammonia) among the experiments performed period.
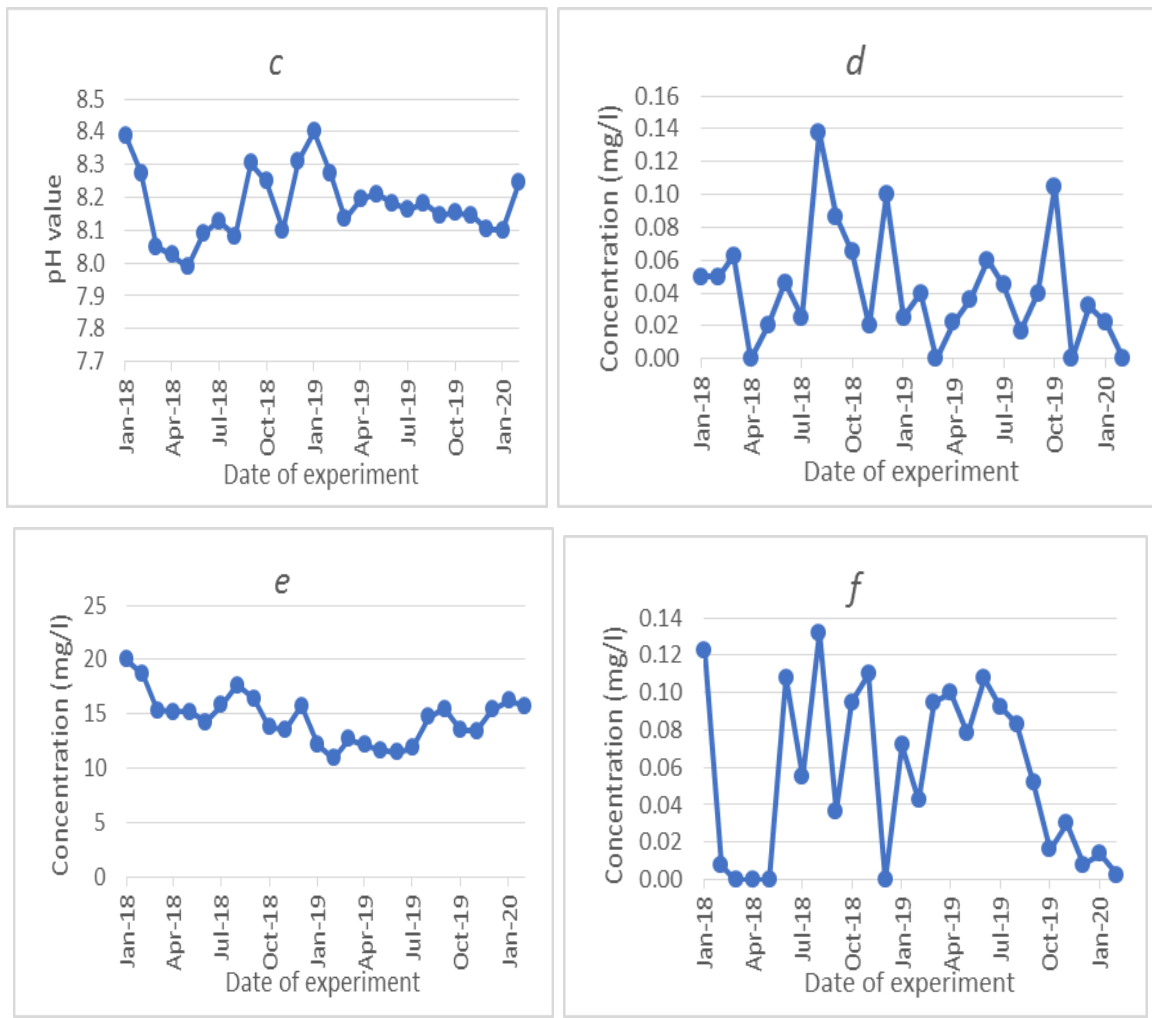

Fig. (3 - c, d, e, f) Chemical parameters versus the period of experiments.

$\mathrm{pH}$ is a scale used to specify the acidity or basicity of an aqueous solution [12], Figs. $(3-\mathrm{c})$ shows the variation of the freshwater $\mathrm{pH}$ value over the experiments period and it was observed that the maximum value of $\mathrm{pH}$ was 8.4 , and the minimum was 8.0 , seasonally $\mathrm{pH}$ average values were ( 8.3 in winter, 8.1 in spring, 8.2 in summer, and 8.2 in autumn) while the average value of $\mathrm{pH}$ was calculated as 8.2.

All obtained results of $\mathrm{pH}$ values comply the established limits of $\mathrm{pH}$ in the Egyptian national drinking water standards of the Egyptian health minister decree 458/2007, which must be within range of $6.5-8.5$. 
The study of Water quality assessment of river Nile from Idfo to Cairo obtained seasonally $\mathrm{pH}$ average values of Nile River surface water in the midstream as (7.63 in winter, 8.60 in spring, 7.50 in summer, and 7.69 in autumn) with average of 7.90 overyear of 11 water quality monitoring sites on the Nile River stream from Idfo city in the Upper Egypt to the capital city Cairo [7].

Figs. (3 - d) shows the variation of the iron concentrations in the freshwater samples over the experiments period and it was observed that the maximum concentration of iron was $0.14 \mathrm{ppm}$, and the minimum was nil, seasonally iron concentrations as $(0.04$ ppm in winter, $0.02 \mathrm{ppm}$ in spring, $0.06 \mathrm{ppm}$ in summer, and 0.06 ppm in autumn) while the average concentration for iron was calculated as $0.04 \mathrm{ppm}$.

The obtained iron concentrations comply the established limits in the Egyptian national drinking water standards of the Egyptian health minister decree 458/2007, which must not exceed $0.3 \mathrm{ppm}$.

While the study of microbiological and chemical study obtained seasonally iron concentrations as $(0.73 \mathrm{ppm}$ in winter, $0.84 \mathrm{ppm}$ in spring, $0.60 \mathrm{ppm}$ in summer, and $0.83 \mathrm{ppm}$ in autumn) with average of $0.75 \mathrm{ppm}$ over-year [5].

Higher chloride concentrations in potable water cause a salty taste [13]. Figs. $(3-$ e) shows the variation of the chloride concentrations in the freshwater samples over the experiments period and it was observed that the maximum concentration of chloride was $20 \mathrm{ppm}$, and the minimum was $11 \mathrm{ppm}$, seasonally chloride concentrations as (15.6 ppm in winter, $13.7 \mathrm{ppm}$ in spring, $14.5 \mathrm{ppm}$ in summer, and $14.3 \mathrm{ppm}$ in autumn) while the average concentration of chloride was calculated as $15 \mathrm{ppm}$.

All obtained chloride concentrations comply the established limits of chloride in the Egyptian national drinking water standards of the Egyptian health minister decree 458/2007, which must not exceed $250 \mathrm{ppm}$. 
While the study of Indices of water quality and metal pollution of Nile River, Egypt obtained seasonally chloride concentrations as (17.33 ppm in winter, $12.3 \mathrm{ppm}$ in spring, 11.2 ppm in summer, and $17.82 \mathrm{ppm}$ in autumn) with average of 14.66 ppm over-year [6].

The ammonia ions in rivers freshwater is generated by industrial processes or is released from proteinaceous organic matter and urea [14]. Figs. (3 - f) shows the variation of the ammonia concentrations in the freshwater samples over the experiments period and it was observed that the maximum concentration of ammonia was $0.13 \mathrm{ppm}$, and the minimum was nil, seasonally ammonia concentrations were $(0.03 \mathrm{ppm}$ in winter, $0.05 \mathrm{ppm}$ in spring, $0.10 \mathrm{ppm}$ in summer and $0.06 \mathrm{ppm}$ in autumn) while the average concentration of ammonia was calculated as 0.06 ppm.

All obtained ammonia concentrations comply the established limits of ammonia in the Egyptian national drinking water standards of the Egyptian health minister decree 458/2007, which must not exceed $0.5 \mathrm{ppm}$.

The study of Water quality assessment of river Nile from Idfo to Cairo obtained seasonally ammonia concentrations of Nile River surface water in the midstream as $(0.419 \mathrm{ppm}$ in winter, $0.324 \mathrm{ppm}$ in spring, $0.583 \mathrm{ppm}$ in summer and $0.279 \mathrm{ppm}$ in autumn) with average of 0.40 over-year [7].

\section{Conclusion}

The assessment of the Nile River freshwater quality is the main way to establish the targeted pollutants to be removed and the treatment methods to produce drinking water complying the local standards of Egypt as established in Egyptian health minister decree 458/2007.

The experiments results with their implementations shows that the main Nile River pollutants are the bacterial count and the turbidity parameters over the experimented parameters (bacterial count, total dissolved solids, turbidity, $\mathrm{pH}$, iron, chloride and 
ammonia) as both of bacterial count and turbidity parameters exceeding the established limits of the local drinking standards as the maximum, minimum, and average values.

Eventually, the treatment technologies and methods of producing drinking water from the Nile River freshwater should consider to get deal with the main freshwater pollutants such as bacterial count and turbidity than other pollutants to comply the local drinking water standards.

\section{References}

1. Liu, S., Lu, P., Liu, D., Jin, P. and Wang, W.: "Pinpointing the sources and measuring the lengths of the principal rivers of the world," Int. J. Digit. Earth, vol. 2, no. 1, pp. 80-87, 2009, doi: 10.1080/17538940902746082.

2. P. H. Gleick: Water in crisis: A Guide to the World's Fresh Water Resources, vol. 9. New York: New York : Oxford University Press, 1993.

3. Alavian, V., Qaddumi, H. M., Dickson, E., Diez, S. M., Danilenko, A. V., Hirji, R. F., Puz, G., Pizarro, C., Jacobsen, M. and Blankespoor, B.: Water and Climate Change: Understanding the risks and making Climate-smart investment decisions, no. November. 2009. [Online]. Available:

http://www.preventionweb.net/files/12832_wbwater.pdf

4. Guidelines for Drinking-water Quality, 4th ed. World Health Organization, 2017.

5. G. H. Ali, G. E. El-Taweel, M. M. Ghazy and M. A. Ali: "Microbiological and chemical study of the nile river water quality," Int. J. Environ. Stud., vol. 58, no. 1, pp. 47-69, Dec. 2000, doi: 10.1080/00207230008711316.

6. A. M. Abdel-Satar, M. H. Ali and M. E. Goher: "Indices of water quality and metal pollution of Nile River, Egypt," Egypt. J. Aquat. Res., vol. 43, no. 1, pp. 21-29, 2017, doi: 10.1016/j.ejar.2016.12.006. 
7. Amaal M. Abdel-Satar: "Water quality assessment of river Nile from Idfo to Cairo," Egypt. J. Aquat. Res., vol. 31, no. 2, pp. 200-223, 2005.

8. R. B. Baird: Standard methods for the examination of water and wastewater, 23rd. American Public Health Association, American Water Works Association and Water Environment Federation, 2017.

9. M. J. Allen, S. C. Edberg and D. J. Reasoner: "Heterotrophic plate count bacteria - what is their significance in drinking water?," Int. J. Food Microbiol., vol. 92, no. 3, pp. 265-274, 2004, doi: 10.1016/j.ijfoodmicro.2003.08.017.

10. J. M. Wilson, Y. Wang and M. A. P.E.: "Sources of High Total Dissolved Solids to Drinking Water Supply in Southwestern Pennsylvania," J. Environ. Eng., vol. 140, no. 5, p. B4014003, May 2014, doi: 10.1061/(ASCE)EE.19437870.0000733 .

11. M. A. Nkansah, J. Ofosuah, and S. Boakye: "Quality of groundwater in the Kwahu West district of Ghana," Am. J. Sci. Indust. Res, vol. 1, pp. 578-584, 2010.

12. W. B. Jensen: "The Symbol for $\mathrm{pH}$, , J. Chem. Educ., vol. 81, no. 1, p. 21, Jan. 2004, doi: 10.1021/ed081p21.

13. A. J. Whelton, A. M. Dietrich, G. A. Burlingame, M. Schechs and S. E. Duncan: "Minerals in drinking water: impacts on taste and importance to consumer health," Water Sci. Technol., vol. 55, no. 5, pp. 283-291, Mar. 2007, doi: 10.2166/wst.2007.190.

14. M. Rawway, M. Kamel and U. Abdul-Raouf: "Microbial and Physico-Chemical Assessment of Water Quality of the River Nile at Assiut Governorate (Upper Egypt)," J. Ecol. Heal. Environmen, vol. 4, pp. 7-14, Jan. 2016, doi: 10.18576/jehe/040102. 


\section{المفص العربي}

\section{تقييم جودة المياه العذبة لنهر النيل}

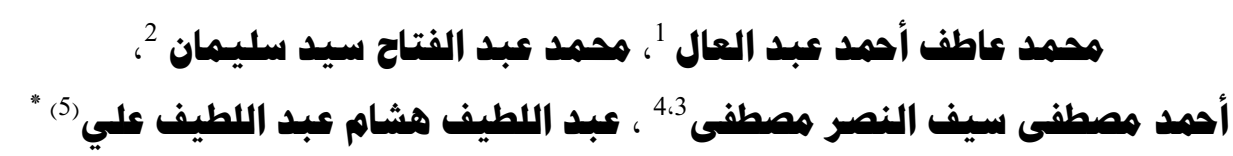

() ثنركة مباه النهرب والصرف الصحبي بأسبوط والوادهي الجبهبه، أسبيوط، مصر.

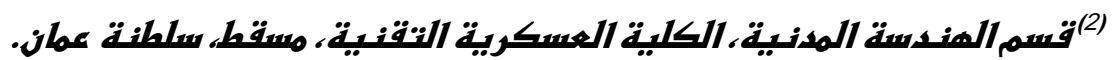

() قسم:الجيولوهيا. كابية العلوم، بامعة أسبوط، مصر.

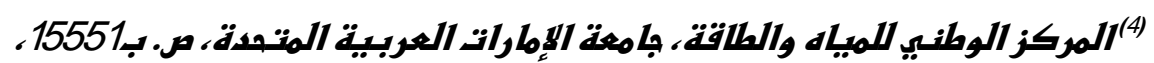

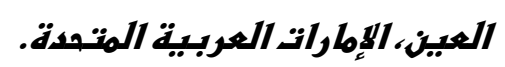

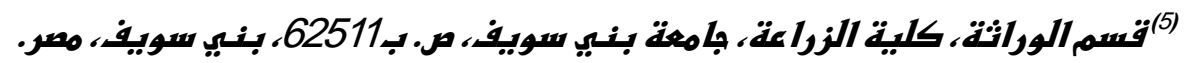

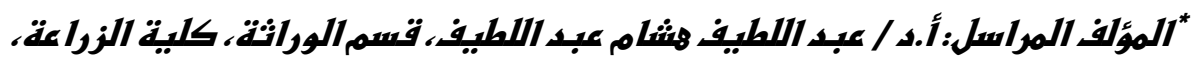

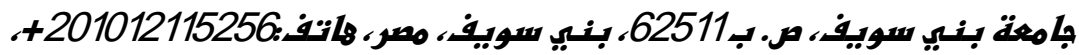

Email:hesham_egypt5@agr.bsu.edu.eg; hesham_egypt5@aun.edu.eg

نهر النيل هو الأطول في إفريقيا والعالم وهو أحد أهم مصادر المياه العذبة. تختلف مواصفات المياه على طول مجرى النهر، الذي يمثل المصدر الرئيسي لمياه الثرب في مصر، بالاعتماد على معالجة المياه العذبة الخام بواسطة محطات تقليدية للتخلص من الملوثات الرئيسية بتلك المياه، مثل الجسيمات العالقة (العكارة) و الكائنات الحية الدقيقة، لذلك فإن تقييم خصائص المياه العذبة للتهر على مدار فترة طويلة ودراستها يفتح العديد من الآقاق لتطبيق وإقرار تقتيات جديدة لمعالجة المياه العذبة، ويعد الهدف الرئيسي من هذه الدر اسة هو رصد جودة المياه بنهر النيل على مدى فترة بمنطقة الدراسة أسيوط - مصر، حيث توضح هذه الاراسة أن نهر النيل يحتوي على كميات كبيرة من البكتيريا بمتوسط 1645 CFU/ml على مدار العام في مواسم 
مختلفة والتي لها تأثير على أعداد هذه البكتيريا باختلاف المواسم، بالإضافة لاحتواء النهر على تركيزات معتدلة من إجمالي المواد الصلبة الأبية بمتوسط 216 ppm ومتوسط عكارة حوالي 4.7 NTU ، بينما كان متوسط قيمة الأس الهيدروجيني 8.2 ، وكذلك تركيزات منخفضة من الحديا حيث كان المتوسط 0.04 ppm، وتركيزات معتدلة من الكلوريدات بمتوسط 15 ppm وتركيزات منخفضة من الأمونيا بمتوسط 06 ppm، وعليه فإن تلك الاراسة هي تقييم لمواصفات مياه نهر النيل للتأكيد أن المياه العذبة يتطلب معالجتها من القيم غير المطابقة للبكتيريا والعكارة لمطابقة معايير مياه الثرب المصرية.

\section{otoces}

